\title{
String Quartet as Autoethnography: The Writing of Out of the Snowstorm, an Owl (2014-17)
}

\section{Lucy Hollingworth}

My string quartet, "Out of the Snowstorm, an Owl" was begun in 2014, but personal circumstances delayed its completion until 2017. It received its premiere at the Royal Conservatoire of Scotland in 2018, performed by the Brodick Quartet. In the present inquiry, I will explain how this music was created in response to the transformation of my life and the recovery of my lost career as a composer, and was also impacted by a devastating bereavement that I experienced during the three years of its incubation. I will situate the circumstances surrounding the piece within the context of the creative lives of other women composers with particular reference to Ruth Crawford and Ethel Smyth, and I will explore how a piece of music can function as part of a creative autoethnography. The full score and a recording of "Out of the Snowstorm, an Owl" is provided to elaborate and elicit enhanced meanings for the reader.

Keywords: autoethnography, Ethel Smyth, Ruth Crawford, string quartet, woman composer

You went out and told me that ... I should go and walk in the picnic area. I did, sometime around noon, the snow was deep and it was difficult to walk around. My feet made lots of holes in the snow. I stood by the burn and cried. I was out in the snow for about half an hour. I went back in the house and sat in the armchair... You came back and you were sitting on the settee. I think you were asleep for a while ... While I was in the chair I felt like a massive pressure was physically lifted from my stomach and rib cage. I also started to feel, to let feelings flow in me. I have been crushing everything. I can recall telling [someone] years ago (in the eighties) that I felt like there was a tight knot in my stomach just below the diaphragm. As I sat in that chair the knot, the tension, started to lift from me, like the mist clearing and things getting into clarity. The feeling was incredible and almost impossible to describe. I cried a bit, I think you cried as well. The experience of release continued for about two hours. I have felt completely different-like a different person-ever since then. If there could ever have been any doubt about whether I had done the right thing for myself by

(C) Lucy Hollingworth. The content of this article is the sole responsibility of the author. The ACT Journal and the Mayday Group are not liable for any legal actions that may arise involving the article's content, including, but not limited to, copyright infringement. 
leaving [...], then this was the certain evidence that I needed to leave him for myself, for my own well being... We saw the barn owl-you collapsedyou said you felt that it happened because you were safe-because I was there. We saw the owl again the following day (Hollingworth 2009).

$\mathrm{T}$ hat extract from my personal diary describes events that took place two days after I took action to change my life completely in 2009. In the following pages, I will explain how I arrived at this extraordinary day, how I came to write the string quartet Out of the Snowstorm, an Owl, which I completed in 2017, and how I came to understand that the composition process and my actual work was, in fact, autoethnographic. First, I will provide some background about my life story that led to these events.

I graduated from Manchester University with a Bachelor's degree in music in 1982 and planned to start a Master's degree after a short gap. I worked freelance undertaking instrumental teaching and performing new music. In 1986, I won the Yorkshire Arts Association Young Composers' Competition with my first string quartet, Two Fragments and a Coda, but the performers told me it was unplayable, so it was not performed. I continued to struggle on with very little support and encouragement. In 1988, I had a score performed at a workshop organised by the Society for the Promotion of New Music, but the piece and the method of notation I had used was severely criticised and I felt humiliated at the public event. I became a member of an ad hoc group called North East New Music, which was funded by Northern Arts and I also wrote a piece for a commission from the viola player Susan Bicknell. During this time, I embarked on a relationship with the man who became my first husband and we married in 1985. My husband, who had been very encouraging and who said it was wonderful to have fallen in love with a composer, started to put obstacles in the way of my ever actually starting the masters' degree. Little by little, in the early 1990s, I stopped composing and in the end, I ceased being a musician at all. My husband expected me to live his life, not my own. I fell into a very deep depression and did almost nothing at all for three years.

Eventually, I managed to pull myself out of the depression and began to look for a way forward. I went to college and studied Information Technology. I secured a job as a lecturer in IT and later worked in conservation as an Information Officer. As I gained my confidence at work, and some financial independence, I started to realise how others had controlled my life-especially my husband. In 2005, my

Hollingworth, Lucy. 2019. String Quartet as Autoethnography: The Writing of Out of the Snowstorm, an Owl (2014-17). Action, Criticism, and Theory for Music Education 18 (2): 147-56. https://doi.org/10.22176/act18.2.147 
brother died at the age of 49 . I was then 44 . It shook me and I realised that I might die without ever having achieved my ultimate ambition.

One night in the winter of 2009, I finally left my husband. I packed some possessions into my car and drove away from the life that had silenced my compositional voice, through a snowstorm, to the house of a friend in the North Pennines where I knew I would be safe. It was two days later that we saw the owl. It suddenly appeared into view. It glided silently down onto a fence post outside the window. My friend was so surprised that he fainted. It was still there when he came round and we watched it as it surveyed the snow-covered world, looking for movement. How hungry must it have been? Then, just as suddenly, it launched itself into the air again and was gone.

This was a pivotal moment in my life. Against all the odds, I found myself able to choose my own way forward. My friend, who had supported me during this time of need, became my partner and for the first time in my life I found myself in a relationship in which I was truly an equal. At first I felt unable to return to music, particularly to being a composer. I had closed some part of my mind to it in order to survive. I did not want to take the risk of starting again. My new partner encouraged me to see a psychotherapist and to work through my experiences. He bought me a piano and suggested I try playing again. He encouraged me to leave my IT job. I am sure that he did not really want me to spend as much time away from home as I eventually did, but he saw very clearly that I had abandoned my creative work as a composer because of extremely destructive events in my life, and he wanted to make a difference for me. He offered to support me through a masters' degree in composition, which I gained with distinction 25 years after I had originally envisaged completing it.

The return to composition as a postgraduate student was both challenging and frightening. It was challenging because I needed to rediscover my creative self, and it was frightening because I was anxious about exposing my creative self to judgement and criticism again, at an age approaching 50. Toward the start I tried to disregard the composer I had been previously, to start afresh. It soon became clear to me, however, that my past work was a part of me that I could not disregard, and that without reconciling the present with past work I would be unable to move forward. I entered into a period of intense self-reflection, an investigation into how my past might impact upon my new life as a postgraduate student. As the poet and academic Carl Leggo has written, "[T] he stories we write and tell about our living

Hollingworth, Lucy. 2019. String Quartet as Autoethnography: The Writing of Out of the Snowstorm, an Owl (2014-17). Action, Criticism, and Theory for Music Education 18 (2): 147-56. https://doi.org/10.22176/act18.2.147 
experiences will teach us how to live with more creativity, confidence, flexibility, coherence, imagination, and truthfulness" $(2005,132)$. That process of self-reflection set in motion my interest in creative autobiographical work using music and words, and helped me to grow again as a composer.

With the continuing support and encouragement of my partner, I began a $\mathrm{PhD}$ in composition at the Royal Conservatoire of Scotland, Glasgow. Here the opportunity arose for a performance of my string quartet Two Fragments and a Coda, and it received its premiere in 2014, nearly 30 years after it had been written. This was a deeply moving moment in the recovery of my creative self. I felt vindicated in my original intentions in writing the piece that had been rejected for performance. The premiere also demonstrated that the piece was not 'unplayable' after all.

I developed plans to write a dissertation on women composers as part of my $\mathrm{PhD}$ studies. I started to listen to as much music composed by women as I could, and to read their biographies where these were available. I discovered Ruth Crawford's String Quartet written in 1931 and I was astounded by the work, by its intensity and focus, but also surprised that such an extraordinary piece was not better known. I began to read about Crawford's life and I discovered that shortly after writing this work, while at the peak of her creative powers, she stopped composing music altogether for almost 20 years. Given the clear parallels to my own story, I felt a powerful connection with her.

Crawford attempted to forge her career in the very male-dominated environment of modernist music in the United States and found herself part of a group that was essentially hostile to her presence despite acknowledging her achievements. In 1930, she was forced to sit outside the room during a meeting of the New York Musicological Society (a predecessor of the current American Musicological Society). Of this event, her husband Charles Seeger said, "we wanted to make it perfectly clear that we were men, and that we had to talk about music, and women weren't in on it" (quoted in Tick 1997, 122). When Crawford married Seeger she had anticipated a partnership in which they raised a family together and were mutually sympathetic, and in which he would be supportive of her work as a composer. But it did not come to pass. Charles Seeger moved into ethnomusicology and did not continue to encourage his wife's work. Neither did he help in practical ways to raise the children. He is described as having had a very conservative view about the responsibilities of women (307). Crawford, meanwhile, felt an "anxiety of

Hollingworth, Lucy. 2019. String Quartet as Autoethnography: The Writing of Out of the Snowstorm, an Owl (2014-17). Action, Criticism, and Theory for Music Education 18 (2): 147-56. https://doi.org/10.22176/act18.2.147 
authorship," a feeling of inadequacy as a composer. ${ }^{1}$ In 1929 she wrote, "I ask myself why under God's heaven, I am a composer. I say damn, I ask what I am good for. I am not brilliant along any line [sic], I do nothing easily. Have I anything to say?" (quoted in Straus 1995, 212). She fell into a depression and then threw herself into her husband's work on traditional music.

I began to understand that Ruth Crawford had found herself, a young female composer in a man's world, married to a man who did not really want her to succeed, just as I had. And, like me, she had too many self-doubts to stand firm and follow her ambitions. The parallels did not end there. After a long period of silence as a composer, she had similarly found the strength to return. For her, there were two significant pivotal events. One was the completion of her 1948 book American Folk Songs for Children, which had been seven years in preparation. Crawford wrote that she was "out of exile-book and teaching exile" (Tick 1997, 311). Then in the same year, Edgard Varèse wrote to her asking for information about her work for a course he was teaching at Columbia University. In her reply she wrote:

I am still not sure whether the road I have been following the last dozen years is a main road or a detour. I have begun to feel, the past year or two, that it is the latter-a detour... I ... felt somewhat like a ghost when my compositions were spoken of... Whether I ever unfold the wings and make a start toward the stratosphere again, and how much of the dust of the road will still cling to me, is an interesting question, at least to me. If I do, I will probably pull the road up with me (quoted in Gaume 1986, 213).

Crawford went on to write a new work, her Wind Quintet, in 1952, for which she won a composition prize from the National Association for American Composers and Conductors that year. Her daughter Peggy said of her that at this time she was "almost like a new person; it was almost like a new life" (quoted in Tick 1997, 315). In a letter to Carl and Charlotte Ruggles, Crawford wrote, "I have for the first time since 1934 finished a thing of some length. It has been a most wonderful feeling... I believe I'm going to work again-more. If I live to be 99 as my grandfather did, that gives me 48 more years." (quoted in Tick 1997, 315)

Crawford did not, however, have another 48 years; she lost her life to cancer shortly thereafter in 1953. For me, the fact that she started again with the work that she clearly loved the most, her compositional activity, and gave the world more of her art music, is the most positive part of her biography.

As for my own continuing story, I began to write a piece for violin and viola soon after I commenced my PhD in 2013, but quickly realised that the music

Hollingworth, Lucy. 2019. String Quartet as Autoethnography: The Writing of Out of the Snowstorm, an Owl (2014-17). Action, Criticism, and Theory for Music Education 18 (2): 147-56. https://doi.org/10.22176/act18.2.147 
required larger instrumental forces and began to consider the possibility of a second string quartet. But my partner suddenly became very poorly and was diagnosed with cancer. During a long stay in hospital he acquired an infection and chemotherapy became impossible. We married in March 2014, and he died in July of the same year. He only ever heard the early sketches for the new piece.

After his death, I gradually returned to my $\mathrm{PhD}$ studies, composing What The Living Do for solo piano, which was a response to my loss, followed by The Poetess, a semi-autobiographical music theatre work about the struggle to survive abusive relationships. It became clear to me that the $\mathrm{PhD}$ was becoming more autobiographical than I had originally imagined it would be, and I began to explore autoethnography as a suitable methodology to adopt, because I started to understand that what I had to say was as much about women's experiences more widely as about my own individual circumstances.

In Gender and the Musical Canon Marcia Citron (1993) writes that "patriarchal society has captured the concept of creativity and deployed it as a powerful means of silencing women" (45). Citron describes the way that society's imposition of roles upon women has suppressed their creativity both historically and in the modern era. As I continued my research into the lives and work of women composers I came across another composer, Ethel Smyth, who had also struggled against patriarchy in order to obtain recognition for her music. I was struck by the story of the writing of her String Quartet in E minor, another extraordinary work which, like Crawford's string quartet, deserves to be better known, and to which I also felt a powerful connection.

Smyth had begun the piece in 1902 but had abandoned it after writing two movements. In 1912 she returned to it and completed it by adding the last two movements. It received its premiere the following year. Smyth had undertaken little composing during these years, partly because she had spent a great deal of time trying to secure productions of her opera The Wreckers in the male-dominated opera world (St. John 1959, 106-114), partly because of the death, in 1908, of her long-standing friend and collaborator Henry (Harry) Brewster, and partly because in 1910 she pledged two years dedicated to the women's suffrage cause. Over two decades later she was to write concerning the reception of her string quartet that "suddenly I realized how wrong I had been to abandon my musical career when Harry died. I resolved to go back to London at once and resume it. I knew that in this lay my sole hope of being ultimately healed" (quoted, 132). Elizabeth Wood

Hollingworth, Lucy. 2019. String Quartet as Autoethnography: The Writing of Out of the Snowstorm, an Owl (2014-17). Action, Criticism, and Theory for Music Education 18 (2): 147-56. https://doi.org/10.22176/act18.2.147 
reads the completion of the quartet as an act of rebellion against the patriarchy coincident with her period of service to the suffragette movement.

How better prove, both to herself and the musical establishment, a woman's equal rights in music's body politic, and the power of female desire and creativity to conquer male prejudice and exclusion, than to demonstrate "mastery" of the supremely mainstream classical string quartet tradition of Beethoven and Brahms in which she was trained? (Wood 1995, 623)

The discovery of Smyth's story of loss and recovery as a composer reinforced my feeling that my work needed to reflect the experiences of other women composers as autoethnography rather than simply autobiography. Carolyn Ellis describes autoethnography as "research, writing, story, and method that connects the autobiographical and personal to the cultural, social, and political" (Ellis 2004, xix). Gouzouasis and Ryu $(2015,403)$ reveal how, in writing autoethnography, "we are wholly engaged with the self and others in our stories and storytelling." My compositions tell my story in such a way that an audience can actively interpret it through sound and feeling as well as through reading a text. But they also encompass the story of the other women composers who have had similar experiences.

Kim Etherington (2004) writes that "creative depictions give data a life and dimension that convey the visual, intellectual, bodily and emotional qualities of the experiences being studied" (150). She was referring specifically to the use of the visual arts in autoethnography, but the idea can apply equally well to music as an aural and embodied experience. My compositions are conceived as practice-as-research; the musical works are the research just as much as the written texts associated with them. In this sense they represent a form of living inquiry, they are about "being in the world but also what constitutes our belonging in the world" (Meyer 2010, 86). As a lifelong learner in the arts, composition became a tool for rediscovery about myself and my capacity as a researcher. Gouzouasis has written, "As a musician, I think about all of my life experiences and music expertise and how that influences my perspectives of music creation, music making, music learning, and music research" $(2013,7)$. This reflection also rings true for me.

The sketches for my string quartet remained incomplete until I was offered a commission by the Royal Conservatoire of Scotland for its "Plug 2018" festival of new music. Listening again to the music I had written back in 2013, I felt the powerful mood of transformation, an expression of how I had turned my life around, and I remembered the owl which seemed to have been a harbinger of the huge

Hollingworth, Lucy. 2019. String Quartet as Autoethnography: The Writing of Out of the Snowstorm, an Owl (2014-17). Action, Criticism, and Theory for Music Education 18 (2): 147-56. https://doi.org/10.22176/act18.2.147 
changes that were coming my way after I left my first marriage. And so Out of the Snowstorm, an Owl came into being. This mood of transformation speaks not just for me, but also for my ethnographic "others"-Crawford, Smyth and countless other women who have found themselves unable to create without having to resist and oppose social expectations.

I will not enter into any greater detail here concerning the music itself, because my hope is that by listening to my piece, the reader will gain a personal understanding of what I have to say about the processes of transformation and of discovering oneself anew. The success of the premiere and the very positive feedback I have received have made a difference to me. They have renewed my energy and resolve to continue to move forwards as a composer and to aim for the levels of achievement that I could only dream of when I was an undergraduate student nearly 40 years ago. The achievement has validated the process of reconciliation within my creative self through this autoethnographic approach to my doctoral research.

The recording of the premiere performance of Out of the Snowstorm, an Owl by the Brodick Quartet can be heard here: https://soundcloud.com/lucy-hollingworth/out-of-the-snowstorm-an-owl and the full score follows the present essay.

\section{Acknowledgements}

I would like to thank the Royal Conservatoire of Scotland for commissioning Out of the Snowstorm, an Owl, Dr. Gordon McPherson and Dr. Christopher Wiley for their invaluable guidance, and the Brodick Quartet for their sympathetic performance.

\section{About the Author}

Lucy Hollingworth is a composer and writer who lives in Scotland. She graduated with a Bachelor's degree in music from Manchester University in 1982. She worked freelance as a performer/composer and was a member of the North East $\mathrm{New} \mathrm{Mu-}$ sic ensemble. She was twice a prizewinner at the Yorkshire Arts Association Young Composers' Competition at the Huddersfield Festival. A commission from the viola player Susan Bicknell resulted in The Endless Knot which was premiered in London in 1994. Then, for many years, circumstances in her life made composing impossible. She resumed her musical career in 2009, studied with Nigel Osborne, obtained a MMus in Composition at Edinburgh University, and is currently pursuing a PhD in Composition and Dissertation at the Royal Conservatoire of Scotland. Her research comprises an autoethnography that examines gender issues in

Hollingworth, Lucy. 2019. String Quartet as Autoethnography: The Writing of Out of the Snowstorm, an Owl (2014-17). Action, Criticism, and Theory for Music Education 18 (2): 147-56. https://doi.org/10.22176/act18.2.147 
relation to music composition. Recent pieces have been performed by Red Note Ensemble, the Brodick Quartet, and the pianist Sinae Lee.

\section{References}

Citron, Marcia J. 1993. Gender and the musical canon. Cambridge: Cambridge University Press.

Ellis, Carolyn. 2004. The ethnographic I: A methodological novel about autoethnography. Walnut Creek: AltaMira Press.

Etherington, Kim. 2004. Becoming a reflexive researcher: Using our selves in research. London: Kingsley.

Gaume, Matilda. 1986. Ruth Crawford Seeger: memoirs, memories, music. Metuchen, NJ: Scarecrow Press.

Gouzouasis, Peter. 2013. The metaphor of tonality in artography. The UNESCO Observatory E-Journal 3 (1): 1-18. https://www.researchgate.net/ publication/255965329_The_metaphor_of_tonality_in_artography.

Gouzouasis, Peter, and Jee Yeon. 2015. A pedagogical tale from the piano studio: Autoethnography in early childhood music education research. Music Education Research 17 (4): 397-420.

Hollingworth, Lucy. 2009. Personal diary. Unpublished manuscript.

Leggo, Carl. 2005. Autobiography and identity: six speculations. Vitae scholasticae 22 (1): 115-33.

Meyer, Karen. 2010. Living Inquiry: Me, My Self, and Other. Journal of Curriculum Theorizing 26 (1): 85-96.

St. John, Christopher. 1959. Ethel Smyth: A biography. London: Longmans.

Straus, Joseph N. 1995. The music of Ruth Crawford Seeger. Cambridge: Cambridge University Press.

Tick, Judith. 1997. Ruth Crawford Seeger: A composer's search for American music. New York: Oxford University Press.

Wood, Elizabeth. 1995. Performing rights: A sonography of women's suffrage. $M u-$ sical Quarterly 79 (4): 606-43.

\section{Note}

Hollingworth, Lucy. 2019. String Quartet as Autoethnography: The Writing of Out of the Snowstorm, an Owl (2014-17). Action, Criticism, and Theory for Music Education 18 (2): 147-56. https://doi.org/10.22176/act18.2.147 
${ }^{1}$ See Citron (1993) for a detailed explanation of the "anxiety of authorship" and its impact on women composers.

Hollingworth, Lucy. 2019. String Quartet as Autoethnography: The Writing of Out of the Snowstorm, an Owl (2014-17). Action, Criticism, and Theory for Music Education 18 (2): 147-56. https://doi.org/10.22176/act18.2.147 